Peer-reviewed scientific periodical, focusing on legal and economic issues of antitrust and regulation. Creative Commons Attribution-No Derivative Works 3.0 Poland License.

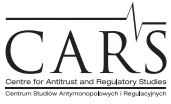

Centre for Antitrust and Regulatory Studies, University of Warsaw, Faculty of Management www.cars.wZ.uw.edu.pl

\title{
Compatibility of Polish Law with EU Law Concerning the Use of Electronic Communications Means for Direct Marketing Purposes
}

\author{
by
}

\author{
Artur Salbert*
}

\section{CONTENTS}

I. Introduction

II. EU law on direct marketing

III. Polish law applicable to direct marketing

IV. The evaluation of compatibility of Polish law with EU law

1. Linguistic interpretation

2. Teleological (purpose-driven) interpretation

3. The right to invoke the direct effect of Article 13 of Directive 2002/58/EC

V. Legislative amendments

VI. Conclusions

\section{Abstract}

EU law sets out some requirements in respect of data processing for direct marketing purposes. These requirements are included in particular in Regulation 2016/679 ${ }^{1}$ and Directive 2002/58/EC ${ }^{2}$. The use of electronic communications means

* Dr Artur Salbert, partner at Modzelewska\&Paśnik, Warsaw, ORCID: 0000-0003-01820273, e-mail: artur.salbert@modzelewskapasnik.pl. Article received: 21 July 2019, accepted: 18 October 2019.

1 Regulation (EU) 2016/679 of the European Parliament and of the Council of 27 April 2016 on the protection of natural persons with regard to the processing of personal data and on the free movement of such data, and repealing Directive 95/46/EC (General Data Protection Regulation), OJ L 119, 04.05.2016, p. 1-88.

2 Directive 2002/58/EC of the European Parliament and of the Council of 12 July 2002 concerning the processing of personal data and the protection of privacy in the electronic communications sector (Directive on privacy and electronic communications), OJ L 201, 31.07.2002, p. 37-47. 
for direct marketing purposes has an impact on both the entrepreneurs and their clients' rights, therefore, accurate interpretation of EU law in this respect and an appropriate implementation of EU law into national law in Member States as well as its appropriate application in practice, are essential.

This article provides an analysis of the conformity of Polish law with EU law in respect of the use of electronic means of communication for the direct marketing of products or services similar to products or services previously sold or provided by the same entity. There are a lot of doubts in this regard. The correct evaluation of Polish law with the use of pro-EU rules interpretation is crucial, because Polish law provides severe sanctions for the infringement of provisions concerning the use of electronic means of communications for direct marketing purposes.

\section{Resumé}

La législation de l'UE fixe certaines exigences en ce qui concerne le traitement des données à des fins de commercialisation directe. Ces exigences figurent notamment dans le règlement 2016/679 et la directive 2002/58/CE. Lutilisation des moyens de communications électroniques à des fins de commercialisation directe a une influence tant sur les droits des entrepreneurs que sur ceux de leurs clients; il est donc essentiel d'interpréter correctement le droit communautaire en la matière, de le transposer correctement en droit national et de le faire appliquer correctement dans les États membres. Le présent article analyse la conformité du droit polonais avec le droit communautaire en ce qui concerne l'utilisation de moyens de communication électroniques pour la commercialisation directe de produits ou de services similaires à des produits ou services précédemment vendus ou fournis par la même entité. Il y a beaucoup de doutes à cet égard. L'évaluation correcte de la législation polonaise à travers l'interprétation des règles pro-UE est cruciale car la législation polonaise prévoit des sanctions sévères en cas de violation des dispositions concernant l'utilisation des moyens de communication électroniques à des fins de la commercialisation directe.

Key words: direct marketing; unsolicited communications; right to privacy; opt-in and opt out rules; personal data; legal persons data.

JEL: K24

\section{Introduction}

There is no legal definition of 'direct marketing' in European Law. In addition, apart from the term 'direct marketing', other equivalent or similar expressions are used in European Law. There is a reference to direct marketing in Regulation 679/2016 (recital 47) and Directive 2002/58/EC 
(Article 13). Another legal act, that is Directive 2000/31/EC ${ }^{3}$, relevant to the assessment of the problem presented in this article, refers to 'commercial information' (Article 7). Due to the lack of a legal definition of 'direct marketing', referring to the meaning of this concept in economic sciences is justified. It is accepted that the main feature of marketing is to manage profitable customer relationships. The twofold goal of marketing is to attract new customers by promising superior value, and to keep and grow current customer base by delivering satisfaction (Armstrong et al., 2009, p. 6). Direct marketing is a special type of marketing. Direct marketing covers all market activities which use single level (more direct) communication and/or direct distribution or dispatching to address particular target groups individually. Direct marketing also covers those market-oriented activities which use multilevel communication to ensure direct individual contact (Dallmer, 1997, p. 3).

The importance of direct marketing has increased with the development of technology. Currently, direct marketing carried out with the use of traditional means, namely using traditional mail or distributing leaflets and flyers, has become significantly less important. In the digital age, direct marketing, carried out with the use of new ways of reaching the customer, is of fundamental importance. Promoting products and the image of entrepreneurs by means of e-mail, telephone calls (in particular in mobile networks) or cookies is more effective. Due to the fact the currently direct marketing carried out with the use of traditional means is used very rarely, sometimes this term is understood only in the respect of the use of electronic means (Denley, Foulsham and Hitchen, 2019, sec. 12).

The essence of direct marketing leads to the creation of a specific relationship between entrepreneurs, using electronic means for direct marketing purposes, and the recipients of marketing information. This method of communication causes a conflict between two values. On the one hand, entrepreneurs have an interest in reaching out to as many clients as possible with their offer. Thus, they can expect their sales volume to increase. As a result of such activities, they can gain a competitive advantage. On the other hand, sending messages to clients intrudes on their sphere of privacy. There is a risk that clients would not want to receive such information. Of particular importance are situations when the transmission of information involves the processing of personal data. EU law tries to reconcile all those values and balance the interests of both parties (Piątek, 2003, p. 299). Therefore, appropriate regulations have been adopted in the European Union. Some of these regulations have the form of directives and require implementation into national law. The correct

3 Directive 2000/31/EC of the European Parliament and of the Council of 8 June 2000 on certain legal aspects of information society services, in particular electronic commerce, in the Internal Market (Directive on electronic commerce), OJ L 178, 17.07.2000, p. 1-16. 
implementation of EU directives, and the interpretation of national law in light of the pro-EU interpretation, determines whether the objectives set out in EU law are obtained in particular Member States. There are serious doubts whether regulations in force in Poland regarding the use of electronic communications means for direct marketing purposes are compatible with EU law. Further in this article, an assessment of the compliance of Polish legislation with EU law in this respect will be carried out.

\section{EU law on direct marketing}

One of the basic acts of EU law regulating issues related to direct marketing is Regulation 2016/679. However, the material scope of this legal act is limited. With regard to direct marketing, this legal act relates only to the rules of personal data processing, including the admissibility of their processing. Sending marketing messages to entities which are not identified with the use of personal data (for example: capital companies, the names of which do not include data of natural persons) is outside of the scope of Regulation 2016/679. Recital 47 of Regulation 2016/679 refers directly to direct marketing. It states that the processing of personal data for direct marketing purposes may be regarded as carried out for a legitimate interest. From the above, however, it should not be inferred that in each case it is acceptable to process personal data for direct marketing purposes. In this case, the basis for the processing of personal data is the legitimate interest of the controller or a third party. Such legal basis for personal data processing is set out in Article 6 point 1 letter $\mathrm{f}$ ) of Regulation 2016/679. However, this provision requires an assessment of whether in a given case the legitimate interest pursued by the controller or by a third party is not overridden by the interests or fundamental rights and freedoms of the data subject. The problem of balancing the legitimate interest of the data controller and the rights and freedoms of the data subject has been analysed by the Working Party on the Protection of Individuals with regard to the Processing of Personal Data (the so-called Article 29 Data Protection Working Party). ${ }^{4}$ This evaluation was carried out under Article 7 letter $\mathrm{f}$ ) of Directive 95/46/EC, ${ }^{5}$ that is, on the basis of the EU legal act that has been repealed by Regulation 2016/679. Yet, the basis for personal data processing specified in Article 7 letter f) of Directive 95/46/EC is equivalent to the basis

\footnotetext{
4 Article 29 Data Protection Working Party was set under Article 29 of Directive 95/46/EC.

5 Directive 95/46/EC of the European Parliament and of the Council of 24 October 1995 on the protection of individuals with regard to the processing of personal data and on the free movement of such data, OJ L 281, 23.11.1995, p. 31-50.
} 
of personal data processing specified in Article 6 point 1 letter $\mathrm{f}$ ) of Regulation 2016/679 and as a consequence, the opinion of the Data Protection Working Party is useful for the interpretation of Article 6 point 1 letter $\mathrm{f}$ ) of Regulation 2016/679. In one of its opinions, ${ }^{6}$ the Article 29 Data Protection Working Party tried to assess the conditions on which processing personal data for direct marketing purposes is allowed. In this opinion, the Article 29 Data Protection Working Party considered that the legitimate interest of the controller could justify conventional marketing (in particular traditional, postal mailing), ${ }^{7}$ as well as direct marketing of similar products. ${ }^{8}$ In this regard, the opinion referred to Directive 2002/58/EC, which will be described later in this article. It was highlighted in this opinion however, that it is not possible to establish one rule for the assessment whether the legitimate interest of the controller is more valuable than the interest or fundamental rights and freedoms of the data subject. Article 29 Data Protection Working Party stated that, in order to be relevant under Article 7 letter f), a 'legitimate interest' must therefore: (1) be lawful (that is, in accordance with applicable EU and national law), (2) be sufficiently clearly articulated to allow the balancing test to be carried out against the interests and fundamental rights of the data subject (that is, sufficiently specific), and (3) represent a real and present interest (that is, it cannot be speculative). ${ }^{9}$ By referring to another of its opinions, the Article 29 Data Protection Working Party clarified that compliance with the law has a broader sense and means that it is also necessary to ensure compliance with areas of law other than data protection law (this includes other applicable laws, such as employment, contract, or consumer protection law) ${ }^{10}$ It is also emphasised that the results of the balancing of interests might be especially in favour of the controller in the case where the data subject could foresee the use of its personal data for marketing purposes based on its relationship with the controller (Voight and von dem Bussche, 2017, p. 104).

6 Opinion of Article 29 Data Protection Working Party No. 06/2014 on the notion of legitimate interests of the data controller under Article 7 of Directive 95/46/EC adopted on 9 April 2014.

7 Opinion of Article 29 Data Protection Working Party No. 06/2014 on the notion of legitimate interests of the data controller under Article 7 of Directive 95/46/EC adopted on 9 April 2014, p. 24-25.

8 Opinion of Article 29 Data Protection Working Party No. 06/2014 on the notion of legitimate interests of the data controller under Article 7 of Directive 95/46/EC adopted on 9 April 2014, p. 46.

9 Opinion of Article 29 Data Protection Working Party No. 06/2014 on the notion of legitimate interests of the data controller under Article 7 of Directive 95/46/EC adopted on 9 April 2014, p. 25.

10 Opinion of Article 29 Data Protection Working Party No. 03/2013 on purpose limitation adopted on 2 April 2013, p. 19-20. 
Another act of EU law setting out the conditions for data processing for direct marketing purposes is Directive 2002/58/EC. This Directive was drafted to tackle some of the deficiencies of earlier instruments and to deal specifically with problems from the perspective of electronic communications (Savin, 2013, p. 253). Detailed requirements regarding the use of electronic communication means for direct marketing purposes are set out in Article 13 of Directive 2002/58/EC. This provision applies to unsolicited communications. Article 13 paragraph 1 of Directive 2002/58/EC provides that the use of automated calling and communication systems without human intervention (automatic calling machines), facsimile machines (fax) or electronic mail for the purposes of direct marketing may be allowed only in respect of subscribers or users who have given their prior consent. A valid consent cannot be obtained via a general message sent to prospective recipients of unsolicited communications for direct marketing, requesting their consent to receive such communications. ${ }^{11}$ It goes without saying that the arbitrary collection of information that falls under the scope of Article 13 paragraph 1 of Directive 2002/58/EC by way of automatic means that do not involve the consent of the person concerned, such as the automatic harvesting of personal data from public internet places via software programmes, and their use for unsolicited communications for direct marketing, is not permitted (Asscher and Hoogcarspel, 2006, p. 69).

To determine the full scope of the application of Article 13 paragraph 1 of Directive 2002/58/EC, it is required to refer to the definition of electronic mail. Article 2 letter h) of Directive 2002/58/EC provides that electronic mail means any text, voice, sound or image message sent over a public communications network, which can be stored in the network or in the recipient's terminal equipment until it is collected by the recipient. The definition of electronic mail is broad and intended to be technology neutral. ${ }^{12}$ Recital 40 of Directive 2002/58/EC confirms explicitly that electronic mail covers not only e-mail but also SMS messages. When Directive 2002/58/EC was adopted, it was assumed that the concept of electronic mail covers not only classical e-mail (SMTP ${ }^{13}$ based mail) and SMS messages but also MMS-based mail, messages left on answering machines, voice mail service systems including on mobile services

11 Opinion of Article 29 Data Protection Working Party No. 5/2004 on unsolicited communications for marketing purposes under Article 13 of Directive 2002/58/EC adopted on 27 February 2004, p. 5.

12 Opinion of Article 29 Data Protection Working Party No. 5/2004 on unsolicited communications for marketing purposes under Article 13 of Directive 2002/58/EC adopted on 27 February 2004, p. 4.

13 Simple Mail Transport Protocol. 
and 'net send' communications addressed directly to an IP address. ${ }^{14}$ Since the definition of electronic mail is technologically neutral, as a result of the introduction of new technological solutions, currently the list of services falling under the concept of electronic mail is broader. Such services will also include messages sent using instant messengers, if messages are sent to fixed or mobile numbers covered by a national numbering plan. ${ }^{15}$

For all the ways of using direct marketing mentioned in Article 13 paragraph 1 of Directive 2002/58/EC, it is required to obtain the consent of the addressee before sending marketing information. It means that Article 13 paragraph 1 of Directive 2002/58/EC calls for an opt-in solution (Koenig and others, 2009, p. 540). However, other paragraphs of Article 13 of Directive 2002/58/EC specify certain limitations in terms of the application of the opt-in rule. First, the requirements set out in Article 13 paragraph 1 of Directive 2002/58/EC apply only to addressees who are natural persons. Member States, however, retained the freedom to determine the use of electronic communication means for marketing purposes when messages are sent to entities other than natural persons. The above rule is set out in Article 13 paragraph 5 of Directive 2002/58/EC. Second, paragraph 2 of Article 13 of Directive 2002/58/EC provides an exception to the opt-in rule, which applies to a specific type of addressees provided that certain conditions are met. Article 13 paragraph 2 states that where a natural or legal person obtains from its customers their electronic contact details for electronic mail, in the context of the sale of a product or a service, in accordance with Directive 95/46/EC (currently in accordance with Regulation 2016/67916), the same natural or legal person may use these electronic contact details for direct marketing of its own similar products or services provided that customers clearly and distinctly are given the opportunity to object, free of charge and in an easy manner, to such use of electronic contact details at the time of their collection and on the occasion of each message in case the customer has not initially refused such use. Recital 41 provides additional essential explanation helpful to interpret Article 13 paragraph 2 of Directive 2002/58/EC. It explains that within the context of an existing customer relationship, it is reasonable to allow the use of electronic contact details for the offering of similar products or services, but

14 Opinion of Article 29 Data Protection Working Party No. 5/2004 on unsolicited communications for marketing purposes under Article 13 of Directive 2002/58/EC adopted on 27 February 2004, p. 4.

15 Conclusion resulting from CJ judgment of 5 June 2019, case C-142/18, Skype Communications Sàrl v. Institut belge des services postaux et des télécommunications (IBPT), ECLI:EU:C:2019:460.

16 Pursuant to Article 94 point 2 Regulation 2016/679 references to Directive 95/46/EC shall be construed as references to Regulation 2016/679. 
only by the same company that has obtained the electronic contact details in accordance with Directive 95/46/EC (currently in accordance with Regulation 2016/679). When electronic contact details are obtained, the customer should be informed about their further use for direct marketing in a clear and distinct manner, and be given the opportunity to refuse such usage. This opportunity should continue to be offered with each subsequent direct marketing message, free of charge, except for any costs for the transmission of this refusal.

Article 13 paragraph 3 of Directive 2002/58/EC provides freedom for Member States to choose between the opt-in and the opt-out rule in case of unsolicited communications for direct marketing purposes other than those specified, inter alia, in Article 13 paragraph 2 of Directive 2002/58/EC. It results from the above provision that Member States are not entitled to apply a solution other than the opt-out rule in case of the use of electronic communications means for direct marketing of a company's similar products or services. It leads to the conclusion that a full harmonization principle was adopted in Article 13 paragraph 2 of Directive 2002/58/EC.

This means that Directive 2002/58/EC provides the opt-out model for sending marketing messages to existing clients by means of electronic communications devices, provided that direct marketing relates to a company's own products or services that are similar to those sold or provided to their existing clients. Member States are not entitled to introduce a different solution.

Due to the fact that two EU legal acts - Regulation 2016/679 and Directive 2002/58/EC - define the rules of admissibility for direct marketing and that the principles set out in these legal acts are not the same, the relationship between these legal acts should be determined. First, Regulation 2016/679 applies only to the processing of personal data. Pursuant to Article 4 point 1 of Regulation $2016 / 679$, personal data means any information relating to an identified or identifiable natural person. An identifiable natural person is a person who can be directly or indirectly identified, in particular by reference to an identifier such as name, an identification number, location data, an online identifier, or to one or more factors specific to the physical, physiological, genetic, mental, economic, cultural or social identity of that natural person. In contrast, Directive 2002/58/EC protects not only the right to privacy of individuals. The object of protection extends to legal persons as well as entities without legal personality.

Second, Regulation 2016/679 is of a general nature, that is, it determines any type of personal data processing, unless specific legislation excludes its use, whereas Directive 2002/58/EC deals with data processing as part of a specific activity. Article 3 of Directive 2002/58/EC provides that it applies to the processing of personal data in connection with the provision of publicly available electronic communications services in public communications networks in 
the Community, including public communications networks supporting data collection and identification devices. Directive 2002/58/EC applies if three conditions are met, namely: (1) there is an electronic communications service, (2) the service is offered over an electronic communications network, (3) the service and network are publicly available ${ }^{17}$. Particular provisions of Directive 2002/58/EC may have a complementary or exclusive nature in relation to the provisions of Regulation 2016/679.18

Article 13 paragraph 2 of Directive 2002/58/EC has such a specific nature. Primarily, apart from the processing of personal data, it also defines rules for the use of legal persons' data for direct marketing purposes. In addition, it allows the use of electronic communications means for direct marketing of its own similar products or services without the consent of the data subject. The provision of Article 13 paragraph 2 of Directive 2002/58/EC, contrary to Article 6 paragraph 1 letter $\mathrm{f}$ ) of Regulation 2016/679, does not require the carrying out of an assessment of the controller's interests and the data subject's interests, fundamental rights and freedoms in order to determine whether the data can be processed without the consent of the data subject. With regard to clients who initially did not object to direct marketing, Article 13 paragraph 2 of Directive 2002/58/EC requires clients to be clearly and distinctly informed about the opportunity to object to the use of electronic contact data at the time of its collection and at every opportunity when receiving messages, in a simple and free of charge manner.

\section{Polish law applicable to direct marketing}

Solutions adopted in Article 13 of Directive 2002/58/EC were introduced to the Polish legal system in two legal acts: Act on rendering electronic services ${ }^{19}$ and Telecommunications Law ${ }^{20}$ (Piątek, 2019).

Article 10 point 1 of the Act on rendering electronic services provides that it is prohibited to send unsolicited commercial information addressed

17 Opinion 5/2019 of European Protection Data Board on the interplay between the ePrivacy Directive and the GDPR, in particular regarding the competence, tasks and powers of data protection authorities adopted on 12 March 2019, p. 10.

18 Opinion 5/2019 of European Protection Data Board on the interplay between the ePrivacy Directive and the GDPR, in particular regarding the competence, tasks and powers of data protection authorities adopted on 12 March 2019, p. 13-14.

19 Act on rendering electronic services dated 18 July 2002 (Journal of Laws of Republic of Poland from 2002, No. 144, item 1204).

20 Telecommunications Law of 16 July 2004 (Journal of Laws of Republic of Poland from 2004, No. 171, item 1800). 
to a designated recipient who is a natural person by means of electronic communication, in particular electronic mail. Article 2 point 2 of the Act on rendering electronic services defines commercial information as any information intended, directly or indirectly, to promote the goods, services or image of the entrepreneur or professional, whose right to practice depends on the fulfilment of the requirements set out in separate laws, excluding information that enables communication by means of electronic communication with a specific person and information about goods and services that do not achieve the commercial effect desired by the entity that orders it to be distributed, in particular without remuneration or other benefits from producers, sellers and service providers. In accordance with Article 10 point 2 of the Act on rendering electronic services, commercial information is considered as ordered in case the recipient gave consent to receive such information, in particular, he made available an electronic address identifying him. Sending unsolicited commercial information via electronic means of communication constitutes an act of unfair competition and a misdemeanour. Regulations regarding unsolicited commercial information set out in Article 10 of the Act on rendering electronic services include messages sent by means of electronic communication, that is, in particular electronic mail, SMS and MMS (Chałubińska-Jentkiewicz and Taczkowska-Olszewska, 2019; du Val and Nowińska, 2013).

The other legal act regulating the issue of direct marketing by electronic communications means in Poland is the Telecommunications Law. Article 172 point 1 of the Telecommunications Law states that the use of telecommunications terminal equipment and automated calling systems for direct marketing shall be forbidden, unless a subscriber or an end user has given his prior consent. Article 172 point 2 of the Telecommunications Law provides that the regulations included in Article 172 point 1 of the Telecommunications Law do not violate the prohibitions and limitations concerning the transfer of unsolicited commercial information resulting from other legal acts. A question arises about the relationship between Article 10 of the Act on rendering electronic services and Article 172 of the Telecommunications Law. There are a lot of doubts relating to this relation (Gumularz and Kozik, 2009). It appears that there are two main causes of ambiguity.

The first cause stems from the fact that the Act on rendering electronic services was adopted in 2002, that is, before Poland joined the European Union and before the date of the implementation of Directive 2002/58/EC. ${ }^{21}$ It should

21 Pursuant to Article 17 point 1 of Directive 2002/58/EC, this Directive was to be implemented into national law in Member States by 31 October 2003. Due to the fact that Poland joined the European Union on 1 May 2004, Poland was obliged to implement Directive 2002/58/EC on 1 May 2004. 
be emphasized however, that despite the Act on rendering electronic services being adopted before Poland's accession to the European Union, the purpose of this law was to ensure harmonization between Polish and Community law. Poland was obliged to undertake such activities under the Association Agreement between Poland and the European Union. ${ }^{22}$ It was explained in the written justification to the draft of the Act on rendering electronic services, ${ }^{23}$ that in respect of direct marketing (unsolicited commercial information) the objective of this Act was to adjust Polish law to Directive 2000/31/EC. However, this directive did not determine which rule - the opt-in or the opt-out - Member States were obliged to use. In this respect, Directive 2000/31/EC referred to other EU directives, namely Directives 97/7/EC ${ }^{24}$ and 97/66/EC, ${ }^{25}$ as explained in recital 30 of Directive 2000/31/EC.

Directive 97/7/EC and Directive 97/66/EC provided restrictions regarding the use of automatic calling systems (that is, systems operating without human intervention (Rogalski, 2010) and facsimile machines (fax). It should be added that in Polish literature a view is presented that only voice systems should be regarded as automatic calling systems (Litwiński, 2015, p. 404). It would lead to the position that automatic calling systems do not refer to e-mails, SMS, MMS and other text messages. Such position is rightfully not accepted in jurisprudence. ${ }^{26}$ Article 12 paragraph 1 of Directive 97/66/EC provided that the use of automated calling systems without human intervention (automatic calling machine) or facsimile machines (fax) for the purposes of direct marketing may only be allowed in respect of subscribers who have given their prior consent. Paragraph 3 of this Article limited the application of the above rule to subscribers who are natural persons. Article 12 paragraph 2 of Directive 97/66/EC stated that Member States shall take appropriate measures to ensure that, free of charge, unsolicited calls for purposes of direct marketing, by other means, are not allowed either without the consent of the subscribers concerned or in respect of subscribers who do not wish to receive these calls. In this regard, the above provision stipulated that the choice between these options shall be determined by national legislation. Article 10 paragraph 1 of

22 The Europe Agreement establishing an Association between Poland and the European Communities and their Member States signed on 16 December 1991.

23 The draft of the Act on rendering electronic services http://orka.sejm.gov.pl/Druki4ka. nsf/(\$vAllByUnid)/2C59267728F47C60C1256BA00038A017/\$file/409.pdf.

${ }^{24}$ Directive 97/7/EC of the European Parliament and of the Council of 20 May 1997 on the protection of consumers in respect of distance contracts, OJ L 144, 04.6.1997, p. 19-27.

${ }_{25}$ Directive 97/66/EC of the European Parliament and of the Council of 15 December 1997 concerning the processing of personal data and the protection of privacy in the telecommunications sector, OJ L 24, 30.01.1998, p. 1-8.

26 Court of Competition and Consumer Protection judgement of 11 September 2014, XVII AmT 41/12. 
Directive 97/7/EC provided that the use of automated calling system without human intervention (automatic calling machine) and facsimile machine (fax) requires the prior consent of the consumer. Article 10 paragraph 2 of Directive 97/7/EC required that Member States shall ensure that means of distance communications, other than the above, which allow individual communications, may be used only where there is no clear objection from the consumer. Although the above Acts required prior consent only in case of using automated calling systems or facsimile machines when the information was directed to a subscriber who is a natural person (Directive 97/66/EC) or a consumer (Directive 97/7/EC), the Act on rendering electronic services required prior consent for sending any commercial information addressed to the designated recipient.

To conclude, the Act on rendering electronic services did not implement Directive 2002/58/EC, but primarily adjusted Polish law to other European directives, namely Directive 2000/31/EC, Directive 97/7/EC and Directive 97/66/EC. Poland's accession to the European Union, which involved the need to adapt Polish law to Directive 2002/58/EC, resulted in another change of Polish legislation. Article 172 of the Telecommunications Law was adopted. This provision defines rules for the use of electronic communications means for direct marketing purposes. This Article came into force on 3 September $2004^{27}$ and stipulated the prohibition of the use of automated calling systems for direct marketing, unless a subscriber or an end user has given his prior consent.

A joint interpretation of Article 10 of the Act on rendering electronic services and Article 172 of Telecommunications Law in their original versions leads to the following conclusions. First of all, it was prohibited to send commercial information without the prior consent of the addressee (for direct marketing purposes), if it was addressed to the designated recipient. This prohibition concerned sending commercial information by means of electronic communication (including electronic mail, SMS, MMS). Furthermore, it was not allowed to use automated calling systems for direct marketing purposes without prior consent of the addressee. This meant that in the case of using automated calling systems, the consent of the addressee was required, although the information was not addressed to the designated recipient. The above regulation was supplemented by solutions stipulated in Article 6 paragraph 3 of the Act of 2 March 2000 on the protection of certain consumer rights and the liability for damage caused by a dangerous product. ${ }^{28}$ This provision

27 Despite the obligation to implement Directive 2002/58 /EC on 1 May 2004, Poland implemented this directive on 3 September 2004.

28 Act of 2 March 2000 on the protection of certain consumer rights and on the liability for damage caused by a dangerous product (Journal of Laws of Republic of Poland 2000, No. 22, item 271). 
provided that the use of a telephone, a videophone, a fax, an electronic mail, an automatic calling device or other means of electronic communication in order to submit a proposal to conclude a contract might only take place with the prior consent of the consumer.

The legal status described above was changed on 24 December 2014. Primarily, the Act of 2 March 2000 on the protection of certain consumer rights and the liability for damage caused by a dangerous product was repealed. It means that currently the regulation concerning direct marketing with the use of electronic communication means is included in two legal acts, namely the Act on rendering electronic services and the Telecommunications Law. After amendments, the prohibition of directing commercial information addressed to a designated recipient without prior consent stipulated in Article 10 of the Act on rendering electronic services is limited to natural persons. On the other hand, in addition to the original prohibition of the use of automated calling systems for direct marketing purposes without the prior consent of the addressee, Article 172 of Telecommunications Law stipulates also the prohibition of the use of telecommunications terminal equipment for these purposes. The amendment to Article 172 of Telecommunications Law leads to the conclusion that this provision requires consent of the addressee in each case of using electronic means of communication for direct marketing purposes. A view is presented in literature that the amendments to Article 172 of Telecommunications Law did not change the meaning of this provision (Krasuski, 2015). Such opinion seems unjustified however. It appears that the joint interpretation of Article 10 of the Act on rendering electronic services leads to the conclusion that the use of electronic communication means for direct marketing purposes requires in each case the prior consent of the addressee (Reszczyk-Król, 2017). Such position is presented by the President of the Office of Competition and Consumer Protection. ${ }^{29}$

\section{The evaluation of compatibility of Polish law with EU law}

\section{Linguistic interpretation}

The linguistic interpretation of Polish regulations leads to the conclusion that they provide the opt-in rule (they require consent of the addressee) in all cases of direct marketing by means of electronic communications. Polish regulations do not contains different legal requirements depending on the

29 https://www.senat.gov.pl/gfx/senat/userfiles/_public/k8/dokumenty/stenogram/ oswiadczenia/muchacki/7201o.pdf (20.07.2019). 
addressee of the messages (a natural person or a non-natural person) or the purpose of sending of marketing messages.

The solutions adopted in Polish regulations are different than the solutions specified in Article 13 of Directive 2002/58/EC. In this provision, the opt-in rule is obligatory for the use of automated calling systems and communications systems without human intervention (automatic calling devices), facsimile machines and e-mails (including SMS and MMS) for direct marketing purposes, when the information is directed to a subscriber who is a natural person. However, Member States have the choice between introducing the opt-in or opt-out rule in case of the use of electronic means for direct marketing purposes when information is addressed to entities other than natural persons. It is also crucial that the opt-in rule cannot apply to marketing messages sent via electronic mail (including SMS, MMS and other similar means of sending messages) to clients, if the clients' contact details were obtained in connection with the sale of similar products or services. In this case, Article 13 paragraph 2 of Directive 2002/58/EC requires the application of the opt-out rule.

The above comparison indicates the lack of coherence between Polish and EU regulations. Polish regulations allow the usage of the opt-in rule only. In contrast, Directive 2002/58/EC defines the opt-out rule for sending messages by electronic mail for direct marketing of its own similar products or services. The above inconsistency between Polish and EU regulations is confirmed by the practice of the Polish authority competent to ensure the appropriate fulfilment of the obligations set out in Article 172 of the Telecommunications Law, namely the President of the Office of Electronic Communications (hereinafter: President of UKE). This authority issued a decision imposing a fine of PLN 9.1 million on a company which was sending SMS marketing messages to its own clients without their prior consent. The disclosed description of the questioned practice shows that the SMS contained information about the possibility of using services similar to other services previously offered by this company. Only Article 172 paragraph 1 of Telecommunications Law was indicated as the basis for the imposition of a fine; the decision did not refer to EU regulations. ${ }^{30}$ The sole use of a linguistic interpretation leads to the conclusion that the Polish regulations on direct marketing of its own similar products or services are contrary to Directive 2002/58/EC. They require the application of the opt-in rule for any type of use of electronic communications for direct marketing purposes, while Directive 2002/58/EC requires the optout rule for sending messages by electronic mail for direct marketing of its own similar products or services.

30 Retrieved from: https://www.uke.gov.pl/akt/prezes-uke-nalozyl-kary-na-orange-polskas-a-za-wysylanie-smsow-marketingowych-bez-posiadania-zgod-klientow,139.html (20.07.2019). 
It should be emphasised that the solution adopted in the Polish legal system significantly differs from the solutions adopted in other Member States. The model from Article 13 section 2 of Directive 2002/58/EC is copied into national regulations of most Member States. ${ }^{31}$ Poland's different attitude in terms of direct marketing drew the attention of the European authorities. The European Commission underlined in one of its documents that Polish regulations do not lead to results consistent with Directive 2002/58/EC and therefore should be interpreted taking into account other legal acts. ${ }^{32}$

\section{Teleological (purpose-driven) interpretation}

It is required to verify whether the application of the principles of teleological interpretation would ensure coherence between Polish law and EU law. The teleological interpretation of EU law refers to the treaties objectives or the purposes of secondary legislation (Kalisz, 2007). In the present case it is appropriate to refer to the objectives set out in Article 13 of Directive 2002/58/EC. However, the teleological interpretation method cannot leave aside the legal text, because such action would not be considered as an interpretation of the law (Smolak, 2012). Due to the unambiguous wording of Polish law, in particular due to Article 172 of the Telecommunications Law which stipulates the opt-in rule for any use of electronic communication means for direct marketing purposes, it seems impossible to claim that the opt-out rule could be allowed for direct marketing of company's own similar products or services.

Theoretically, the purpose of amending Article 172 of the Telecommunications Law could support the view that the use of a teleological interpretation leads to different results. The written justification of the draft of the act amending the above provision ${ }^{33}$ indicated that the objective of the amendment was to implement Article 10 of Directive 2002/65/EC ${ }^{34}$. The directive in question

31 Examples: $§ 7$ of Gesetz gegen den unlauteren Wettbewerb (UWG) in Germany, $§ 107$ of Bundesgesetz, mit dem ein Telekommunikationsgesetz erlassen wird in Austria, Article L34-5 of Code des postes et des communications électroniques in France, Regulation 13 of S.I. No. 336/2011 - European Communities (Electronic Communications Networks and Services) (Privacy and Electronic Communications) Regulations 2011 in Ireland.

32 European Commission study: 'ePrivacy Directive: assessment of transposition, effectiveness and compatibility with proposed Data Protection Regulation' 2015, p. 101.

33 http://www.sejm.gov.pl/Sejm7.nsf/druk.xsp?nr=2076 (20.07.2019).

34 Directive 2002/65/EC of the European Parliament and of the Council of 23 September 2002 concerning the distance marketing of consumer financial services and amending Council Directive 90/619/EEC and Directives 97/7/EC and 98/27/EC, OJ L 271, 09.10.2002, p. 16-24. 
concerns distance sale of financial services to consumers ${ }^{35}$. In result, an attempt may be made to argue that the requirement to apply the opt-in rule for direct marketing of company's own similar products or services specified in Article 172 of the Telecommunications Law is limited only to financial services offered to consumers. However, it should be taken into consideration that the Polish legislator explained that, in addition to the implementation of the solution from Directive 2002/65/EC, the amendment to Article 172 of the Telecommunications Law also complements the transposition of Article 13 of Directive 2002/58/EC. ${ }^{36}$ This means that the introduction of the opt-in rule for all cases of direct marketing by means of electronic communications was not a mistake of the Polish legislator as a result of inappropriate implementation of Directive 2002/65/EC. On the contrary, the introduction of such a solution was intended and it referred to the completion of the implementation of Directive 2002/58/EC. Therefore, the use of a teleological interpretation also does not allow the bringing of Polish law in conformity with EU law.

\section{The right to invoke the direct effect of Article 13 of Directive 2002/58/EC}

The incompatibility of Polish law with EU law would be eliminated if it could be possible to omit the application of Polish law and apply Article 13 of Directive 2002/58/EC directly. In other words, there is a question of the right of a refusal to apply Polish law and the direct application of the EU Directive. The Court of Justice established the concept of direct effect of the provisions of EU directives. It is accepted that if the provisions of an EU directive conferring rights on individuals are unconditional, sufficiently precise and clear, individuals may invoke them directly against a Member State, provided that a Member State has failed to implement the directive into national law by the end of the period prescribed or where it has failed to implement the directive correctly (Kornobis-Romanowska, 2007). The provision is clear and precise when it is possible to specify the identity of the addressee of the right, the content of the right and the entity responsible for the implementation of this right. The provision is unconditional if its effectiveness does not depend on the call for additional measures, either national or European (Brodecki et al., 2006). It seems that all of the aforementioned conditions are met in the present case. Article 13 of Directive 2002/58/EC, in particular paragraph

35 Article 10 of Directive 2002/65/WE was previously implemented by the Act of 2 March 2000 on the protection of certain consumer rights and the liability for damage caused by a dangerous product.

36 Sejm (lower chamber of Polish Parliament) print No. 2076, http://www.sejm.gov.pl/Sejm7. nsf/druk.xsp?nr=2076 (20.07.2019). 
2 of this Article providing for the opt-out rule for the use of electronic mail for the direct marketing of the products or services similar to the products or services previously sold or provided, is unambiguous and precise.

However, according to settled case-law, an EU directive cannot by itself impose obligations on an individual, but can only confer rights. Consequently, an individual may not rely on a directive against a Member State where it is a matter of a State obligation directly linked to the performance of another obligation falling, pursuant to that directive, on a third party. ${ }^{37}$ As the case-law of the European Court of Justice emphasises, a directive cannot impose an obligations on individuals and therefore even a clear, precise and unconditional provision of a directive cannot apply in proceedings exclusively between private parties. ${ }^{38}$ This means that the principle of direct effect of a directive has significant limitations. It is not allowed to refer to this principle in horizontal relations, that is, in disputes between individuals. ${ }^{39}$ As a result, an entity intending to commence marketing activities of its own similar products or services will not be able to rely on the direct effect of a directive in relations with the recipients of the marketing messages (its clients). The inconsistency of Polish law with EU law does not exclude the unlawfulness of such activities. The addressee who received the message without giving his prior consent would be entitled to a claim against an entity that used the means of electronic communication for direct marketing purposes.

On the other hand, the situation will be different in relations between the entities (individuals) and state authorities, because a directive may have a vertical direct effect. In such case, entities that used electronic mail for direct marketing purposes of their own similar products or services without prior consent of their clients will have the right to invoke the direct effect of Article 13 paragraph 2 of Directive 2002/58/EC before competent authorities, that is, in particular before the President of UKE and courts controlling the decisions of the President of UKE. Competent authorities should refrain from

37 Inter alia CJ judgement of 7 January 2004, Case C-201/02 Delena Wells v. Secretary of State for Transport, Local Government and the Regions, ECLI:EU:C:2004:12, para. 56; CJ judgement of 17 July 2008, in joined Cases from C-152/07 to C-154/07 Arcor AG \& Co., KGCommunication Services TELE2 GmbH, Firma 01051 Telekom v. GmbHBundesrepublik Deutschland, ECLI:EU:C:2008:426, para. 35.

38 Inter alia CJ judgement of 5 October 2004, in Joined Cases from C-397/01 to C-403/01 Bernhard Pfeiffer (C-397/01), Wilhelm Roith (C-398/01), Albert Süß (C-399/01), Michael Winter (C-400/01), Klaus Nestvogel (C-401/01), Roswitha Zeller (C-402/01) i Matthias Döbele v. Deutsches Rotes Kreuz, Kreisverband Waldshut eV. (C-403/01), ECLI:EU:C:2004:584, para. 109 and CJ judgement of 7 June 2007, Case C-80/06 Carp Snc di L. Moleri e V. Corsi v. Ecorad Srl, ECLI:EU:C:2007:327, para. 20.

39 Inter alia CJ judgement of 5 April 1979, Case 148/78 Pubblico Ministero v. Tullio Ratti. ECLI:EU:C:1979:110. 
actions aimed at forcing entities to obtain the consent of their clients for the purposes of direct marketing of their own similar products or services. As a consequence, the authorities should not apply sanctions (including imposing fines) for the use of electronic mail for direct marketing purposes of their own similar products or services in the absence of the consent of their clients. If such actions are taken, courts supervising the activity of these authorities should refer to the principle of vertical direct effect of Article 13 paragraph 2 of Directive 2002/58/EC and take appropriate measures to eliminate decisions which are not in line with the above provision.

\section{Legislative amendments}

Due to the lack of a possibility to ensure consistency between Polish law and EU law, and the limitations relating to the direct effect of Directive 2002/58/EC, by way of using a teleological interpretation, it is required to amend Polish regulations to ensure the compatibility between Polish law and EU law. However, currently in Poland there are no plans to amend regulations in this respect.

It is probable that the inconsistency between Polish and EU law will be eliminated as a result of changes of EU regulations. Currently, works relating to an EU regulation concerning respect for private life and the protection of personal data in electronic communications ${ }^{40}$ are underway. If a new EU regulation is adopted, Directive 2002/58/EC will be automatically repealed. In respect of direct marketing, the draft of the regulation provides for a solution similar to the one stipulated in Article 13 paragraph of Directive 2002/58/EC. Pursuant to Article 288 of the Treaty on the Functioning of the European Union, a regulation has a general application, is binding in its entirety and directly applicable in all Member States, that is, it does not require transposition into national law. This means that once the regulation comes into force, the provisions of this regulation will automatically apply. Thus, Polish rules regarding the use of electronic communication means for direct marketing purposes will not be used, even if they are not formally repealed. Consequently, the inconsistency between Polish law and EU law will be eliminated from the date of the application of the new EU regulation.

40 Proposal for a Regulation of the European Parliament and of the Council concerning the respect for private life and the protection of personal data in electronic communications and repealing Directive 2002/58/EC (Regulation on Privacy and Electronic Communications), https://eur-lex.europa.eu/procedure/EN/2017_3?qid=1540897892574\&rid=5 (20.07.2019). 


\section{Conclusions}

Current Polish regulations in force, that is, Article 10 of the Act on rendering electronic services and Article 172 of the Telecommunications Law, concerning the use of electronic mail for direct marketing purposes of products or services similar to the products or services previously sold or provided, are contrary to EU regulations. Polish law provides for the opt-in rule in this respect. Failure to comply with the opt-in rule is subjected to a fine of up to $3 \%$ of a company's annual revenue. EU regulations, that is, Article 13 paragraph 2 of Directive 2002/58/EC, provides for the opt-out rule in case of using electronic mail for direct marketing purposes of products or services similar to the products or services previously sold or provided. Member States are not entitled to apply a solution other than that set out in Article 13 paragraph 2 of Directive 2002/58/EC. Therefore, in this respect, a full harmonization approach was adopted in Article 13 paragraph 2 of Directive 2002/58/EC. Requirements needed to invoke the direct effect of Article 13 paragraph 2 of Directive 2002/58/EC are met. This provision is precise, clear and provides for unconditional rights for individuals, namely the right to use electronic mail for direct marketing purposes of products or services similar to the products or services previously sold or provided without prior consent of the addressee. This right does not call for additional measures, either national or European. However, the principle of the direct effect of a directive does not apply to horizontal relations (relations between individuals). This means that entities using electronic mail for direct marketing purposes (communications senders) cannot invoke the direct effect of Article 13 paragraph 2 of Directive 2002/58/EC in relations with the addressees of such messages. In this relation, the inconsistency of Polish provisions with EU regulations does not exclude unlawfulness and the addressees of such messages are entitled to pursue claims against the senders. On the other hand, the principle of the direct effect of a directive applies to vertical relations (vertical direct effect of a directive). As a consequence, the senders of marketing messages are entitled to invoke the direct effect of Article 13 paragraph 2 of Directive 2002/58/EC against state authorities and the authorities should refrain from actions aimed at compelling the use of the opt-in rule in the case of using mail for the direct marketing of products or services similar to products or services previously sold or provided. If Polish authorities apply Polish regulations providing for the opt-in rule, for example by imposing a fine as a result of an activity inconsistent with the above rule, the senders may invoke the direct vertical effect of Article 13 paragraph 2 of Directive 2002/58/EC before Polish courts supervising the activity of these authorities. 
Consistency of Polish and EU regulations regarding the use of electronic communications means for direct marketing purposes can be ensured by introducing amendments into Polish law. Such amendments should ensure that Article 13 paragraph 2 of Directive 2002/58/EC will be appropriately implemented. Consistency of Polish and EU regulations may also be ensured if the form of the EU legal act regulating the use of electronic communication means for direct marketing purposes is changed. Currently, European Union authorities are working on an EU regulation on privacy and electronic communications. The new legal act is to replace Directive 2002/58/EC. EU legislation in the form of a regulation is directly applicable in a Member State. It means that if the EU regulation enters into force, regardless of whether Polish provisions on the use of electronic communication means for direct marketing purposes are formally repealed, only the EU regulation shall apply in this respect.

\section{Literature}

Armstrong, G., Kotler, P., Harker, M., Brennan, R. (2009). Marketing: An Introduction. Pearson Education Limited.

Asscher, L., Hoogcarspel Sjo, A. (2006). Regulating Spam: A European perspective after the adoption of the E-Privacy Directive. Information Technology \& Law Series, The Hague: TMC Asser Press, https://dx.doi.org/10.1007/978-90-6704-711-1.

Brodecki, Z., Drobysz, M., Majkowska-Szulc, S., Pyć, D., Tomaszewska, M., Zużewicz, I. (2006). Traktat o Unii Europejskiej, Traktat ustanawiajacy Wspólnotę Europejska $z$ komentarzem, Warszawa: LexisNexis.

Chałubińska-Jentkiewicz, K., Taczkowska-Olszewska, J. (2019). Świadczenie ustug droga elektroniczna. Komentarz. Legalis (electronic version).

Dallmer, H. (ed.) (2013). Handbuch Direct Marketing. Gabler Verlag:Wiesbaden.

Denley, A., Foulsham, M., Hitchen, B. (2019). GDPR: How To Achieve and Maintain Compliance. London: Routledge, https://dx.doi.org/10.4324/9780429449970.

Du Vaal, M., Nowińska, E. (2013). Ustawa o zwalczaniu nieuczciwej konkurencji. Komentarz. LEX (electronic version).

Gumularz, M., Kozik, P. (2019). Ochrona danych osobowych w marketingu i sprzedaży. Warszawa: C.H. Beck.

Kalisz, A. (2007). Wyktadnia i stosowanie prawa wspólnotowego. Warszawa: Wolters Kluwer.

Koenig, Ch., Bartosch, A., Braun, J.-D., Romes, M. (2009). EC Competition and Telecommunications Law. Kluwer Law International.

Kornobis-Romanowska, D. (2007). Sąd krajowy w prawie wspólnotowym. Warszawa: Wolters Kluwer.

Krasuski, A. (2015). Prawo telekomunikacyjne. Komentarz. Warszawa: Wolters Kluwer.

Litwiński, P. (2015). Art. 172 Prawa telekomunikacyjnego - próba wykładni. Monitor Prawniczy, 8 . 
Piątek, S. (2003). Prawo telekomunikacyjne Wspólnoty Europejskiej. Warszawa: C.H. Beck. Piątek, S. (2019). Prawo telekomunikacyjne. Komentarz. Legalis (electronic version).

Reszczyk-Król, K. (2017). Prawne granice przetwarzania danych osobowych do celów marketingu bezpośredniego bez zgody podmiotu danych - perspektywa prawa polskiego i niemieckiego w świetle Ogólnego rozporządzenia o ochronie danych. Monitor Prawniczy, 19.

Rogalski, M. (2010). Prawo telekomunikacyjne. Komentarz. LEX (electronic version).

Savin, A. (2013). EU Internet Law. Elgar European Law.

Smolak, M. (2012). Wyktadnia celowościowa z perspektywy pragmatycznej. Warszawa: Wolters Kluwer.

Voight, P., von dem Bussche, A. (2017). The EU General Data Protection Regulation (GDPR): A Practical Guide. Springer International Publishing AG. 